\title{
Pengaruh Marketing Mix terhadap Keputusan Pembelian Bibit Tanaman pada Kawasan Lubuk Minturun Kota Padang
}

\author{
Nila Pratiwi, Bayu Pratama Azka \\ Universitas Putra Indonesia YPTK Padang, Indonesia \\ Email: bayupratamaazka@upiyptk.ac.id
}

\begin{abstract}
Seeing the great potential of the plant seed industry in the Lubuk Minturun area in Padang City, this research aims to identifying and analyzing the effect of Marketing Mix (Product, Price, Location, Promotion) on the Purchase Decision of Plant Seeds in the Lubuk Minturun Region of Padang City. The sample in this study was 53 buyers of plant seeds in the lower-lying areas of Padang City. This study uses regression analysis through SPSS software to analyze data, by testing the validity, reliability, classic assumption tests and hypothesis testing in the form of t-test and F-test. The test is carried out in order to determine the effect of independent variables on the dependent variable. Based on the results of this study found that the Marketing Mix (Product, Price, Location, Promotion) has partially different results and can be explained as follows: Product (X1) has a significant effect on the Decision of Purchasing Plant Seeds with a significant level amounted to 0.014. Price $(X 2)$ does not significantly influence the Decision to Purchase Plant Seeds with a significant level of 0.830. Location (X3) has no significant effect on the Decision to Purchase Plant Seeds with a significant level of 0.803. Promotion (X4) has a significant effect on the Decision to Purchase Plant Seeds with a significant level of 0,000. While the results of this study found that Marketing Mix (Product, Price, Location, Promotion) has a significant effect on the Decision to Purchase Plant Seeds with a significant level of 0,000

Keywords: Marketing Mix (Product, Price, Location, Promotion) and Purchase Decision
\end{abstract}

\section{PENDAHULUAN}

Pada masa sekarang dunia usaha memasuki era globalisasi, dimana semua pihak sudah dapat secara bebas memasuki setiap pasar yang dikehendaki baik di dalam negeri maupun di luar negeri tanpa ada batasannya. Melihat kondisi yang demikian, maka sudah seharusnya jika setiap bidang usaha dituntut untuk mengetahui dan mengikuti perkembangan atau perubahan dari setiap kegiatan usaha yang akan dijalankannya. Dalam dunia bisnis modern saat ini, menuntut peranan strategi pemasaran yang dapat menunjang kemajuan suatu usaha bisnis, maju mundurnya kegiatan bisnis akan sangat ditentukan oleh keberhasilan kegiatan pemasaran bisnis tersebut, karena kegiatan pemasaran merupakan kegiatan bisnis yang secara langsung berhubungan dengan masyarakat luas (konsumen). Perusahaan harus secara jelas menetapkan kearah mana aktivitas usaha yang dijalankan dan pihak-pihak mana yang menjadi sasaran dari penjualan produk yang ditawarkan oleh perusahaan tersebut.

Lubuk Minturun selain dikenal dengan obyek wisata pemandiannya, Lubuk Minturun juga salah satu daerah terbesar di kota Padang yang menjual tanaman hias dan pembibitan tanaman buah. Kita bisa melihat sepanjang jalan Lubuk Minturun dan sebagian dari penduduknya bermatapencaharian sebagai penjual tanaman hias dan pembibitan tanaman buah. Sektor tersebut sangat menunjang perekonomian masyarakat Lubuk Minturun.

Berdasarkan Observasi di lapangan, peneliti menemui seorang penjual bibit tanaman yang bernama ibu masni. Ibu masni mempunyai tempat penjualan bibit bunga dan tanaman dan dia menjadi salah satu penjual terbesar di Kawasan lubuk Minturun, Kota Padang, Sumatera Barat. Ibu masni telah menjadi salah satu anggota Koperasi Penjual bibit Bungan dan Tanaman di Kawasan Lubuk Minturun, Kota Padang, Sumatera Barat. Koperasi Penjual bibit Bunga dan Tanaman ini menjadi tempat bertemunya para penjual bibit Bunga dan Tanaman dengan jenis Bunga dan Tanaman yang berbeda-beda. Dalam Koperasi Penjual bibit Bunga dan Tanaman ini para penjual juga bisa melakukan transaksi simpan-pinjam.

Dalam Koperasi Penjual bibit Bunga dan Tanaman ini para penjual saling bertukar informasi mengenai harga, jenis bunga dan tanaman, perawatan dan lain-lain dalam satu acara, 
yaitu arisan. Tetapi, tidak semua anggota Koperasi penjual bibit Bunga dan Tanaman mengikuti acara arisan ini karena biaya, kesibukan dan lain-lain. Oleh sebab itu, tidak semua anggota Koperasi Penjual bibit Bunga dan Tanaman ini memiliki informasi yang sama mengenai harga, jenis bunga dan tanaman, perawatan dan lain-lain, maka akan berdampak pada tidak efektif dan efisienya strategi yang di terapkan oleh penjual bibit tanaman tersebut

Dalam observasi lebih lanjut, peneliti bertemu dengan salah seorang pembeli dari penjual bibit tanaman ini, dia bernama rahmat. Dari penuturan rahmat, kami dapat menyimpulkan bahwa "jika saja para penjual bibit tanaman mampu untuk menjual produk yang lebih baik, dengan harga yang sesuai dengan kualitas produk, maka kami selaku pembeli tidak akan berfikir Panjang untuk membeli produk yang di jual mereka. Dan jika saja para penjual mampu menjual produk nya di lokasi yang strategis dan mudah untuk di jangkau serta dengan promosi yang bagus ke seluruh masyarakat kota padang, maka saya yakin bahwa calon pembeli akan lebih tertarik untuk membeli bibit tanaman ke para penjual bibit tanaman ini”.

Berdasarkan latar belakang penelitian diatas, tergambar bahwa beberapa faktor yang dijelaskan dapat mempengaruhi Keputusan Pembelian bibit tanaman ke penjual bibit tanaman di Kawasan Lubuk Minturun, Kota Padang, Sumatera Barat. Hal ini menguatkan peneliti untuk melakukan penelitian terkait Keputusan Pembelian bibit tanaman pada Kawasan Lubuk Minturun Kota Padang, Sumatera Barat. Peneliti menetapkan Marketing Mix yang akan dianalisis dalam penelitian ini.

Penelitian yang dilakukan oleh Oktavianus Barcelona, et.al (2019) dengan hasil penelitian menunjukan adanya Pengaruh positive dan signifikan Marketing Mix Terhadap Keputusan Pembelian Pada CV. Justiti Motor Lembata. Penelitian yang dilakukan oleh Suhartini (2019) dengan Hasil penelitian menemukan bahwa kualitas produk, harga, lokasi, promosi, orang, bukti fisik, dan proses mempunyai pengaruh yang positif dan signifikan terhadap keputusan pembelian klinik kecantikan di kota Makassar. Selanjutnya penelitian yang dilakukan oleh Eko Winarni (2019) dengan hasil menunjukan terdapat Pengaruh Positive dan signifikan Marketing Mix Terhadap Keputusan Pembelian Produk Jasa Pada Villa Abc Malang.

\section{TINJAUAN LITERATUR}

\section{Bauran Pemasaran (Marketing Mix)}

Dalam menghadapi lingkungan persaingan yang semakin kuat dan ketat, setiap usaha dituntut harus mampu mengoptimalkan sumber daya ekonominya guna meningkatkan daya saing produknya di pasar, serta mampu meramu serangkaian strategi pemasaran yang efektif dan selalu mengembangkan strategi pemasaran tersebut secara terus-menerus serta berkelanjutan. Hal ini dilakukan sebagai upaya untuk meraih keunggulan kompetitif terhadap para penjual bibit tanaman yang menjadi pesaing. Strategi pemasaran yang merupakan alat fundamental yang direncanakan untuk mencapai tujuan perusahaan dengan mengembangkan keunggulan bersaing yang digunakan untuk melayani pasar sasaran (Tjiptono, 2014). Salah satu bentuk strategi pemasaran yang mampu mendukung dalam memasarkan produk untuk menciptakan kepuasan konsumen adalah penggunaan Marketing Mix (bauran pemasaran).

Payne (2012:217) menyatakan bauran pemasaran merupakan salah satu faktor penentu konsumen dalam menentukan suatu keputusan pembelian terhadap suatu produk maupun jasa. Oleh sebab itu, strategi bauran pemasaran menjadi sangat penting karena bauran pemasaran yang terdiri atas elemen-elemen tersebut akan saling mempengaruhi sehingga bila salah satu elemen tidak tepat, maka mempengaruhi strategi pemasaran yang akan dilakukan. Sementara Assauri (2011:198) menyatakan bahwa Bauran pemasaran adalah Salah satu unsur dalam strategi pemasaran terpadu adalah strategi bauran pemasaran yang merupakan strategi yang dijalankan perusahaan, yang berkaitan dengan penentuan bagaimana perusahaan menyajikan penawaran produk pada segmen pasar tertentu, yang merupakan sasaran pasarnya. Jadi dapat disimpulkan bahwa Pengertian dari Marketing Mix adalah himpunan dari variabel yang dikuasai dan dapat digunakan oleh manajer pemasaran untuk menarik konsumen agar dapat mempengaruhi penjualan atau pendapatan perusahaan. 


\section{Produk}

Menurut Tjiptono (2008:95) Produk merupakan segala sesuatu yang dapat ditawarkan produsen untuk diperhatikan, dicari, dibeli, digunakan atau dikonsumsi pasar sebagai pemenuhan kebutuhan atau keinginan pasar yang bersangkutan. Produk yang ditawarkan meliputi barang fisik seperti sepeda motor, komputer, televisi sedangkan produk jasa meliputi restoran, penginapan dan transportasi. Produk bisa berupa manfaat tangible maupun intangible yang dapat memuaskan pelanggan. Produk secara konseptual, yaitu pemahaman subyektif dari produsen atas sesuatu yang bisa ditawarkan sebagai usaha untuk mencapai tujuan organisasi melalui pemenuhan kebutuhan dan keinginan konsumen sesuai dengan kompetensi dan kapasitas organisasi serta daya beli pasar.

Menurut (Kotler dan Keller 2009 :143) Indikator kualitas produk :

1) Kualitas kinerja(atau tingkatan)

2) Keandalan

3) Daya tahan

4) Keistimewaan tambahan.

\section{Harga}

Menurut Assauri (2011:223) mendefinisikan harga merupakan satu-satunya unsur Marketing Mix yang menghasilkan penerimaan penjualan, sedangkan unsur lainnya hanya unsur biaya saja. Harga bisa diungkapkan dengan berbagai istilah misalnya iuran, tarif, sewa, bunga, premium, komisi, upah, gaji, honorarium, spp dan sebagainya. Dari sudut pandangan pemasaran, harga merupakan satuan moneter atau ukuran lainnya (termasuk bunga dan jasa lainnya) yang ditukarkan agar memperoleh hak kepemilikan atau penggunaan suatu barang atau jasa (Tjiptono:2008).

Indikator harga menurut ( Kotler \& Keller, 2009:24) yaitu:

a. Harga terdaftar.

b. Potongan harga.

\section{Lokasi}

Tjiptono (2008:185) mendefinisikan secara garis besar, pendistribusian dapat diartikan sebagai kegiatan pemasaran yang berusaha memperlancar dan mempermudah penyampaian barang dan jasa dari produsen kepada konsumen, sehingga penggunaannya sesuai dengan yang diperlukan (jenis, jumlah, harga, tempat, dan saat dibutuhkan). Dengan kata lain proses distribusi merupakan aktivitas pemasaran yang mampu: (1) Menciptakan nilai tambah produk melalui fungsi-fungsi pemasaran yang dapat merealisasikan kegunaan bentuk, tempat, waktu dan kepemilikkan: (2) Memperlancar arus saluran pemasaran secara fisik dan non fisik. Yang dimaksd dengan arus pemasaran adalah aliran kegiatan yang terjadi diantara lembaga-lembaga pemasaran yang terlibat didalam proses pemasaran. Arus pemasaran meliputi barang fisi, arus kepemilikan, arus informasi, arus promosi, arus negoisasi, arus pembayaran, arus pendanaan, arus penanggung risiko dan arus pemesanan.

Pemilihan tempat atau lokasi memerlukan pertimbangan cermat terhadap beberapa faktor berikut. (Tjiptono, 2014:159)

a. Akses, lokasi yang dilalui atau mudah dijangkau sarana transportasi umum.

b. Visibilitas yaitu lokasi yang dapat dilihat dengan jelas lebih dari jarak pandang normal.

c. Lalu lintas (traffic,) menyangkut kepadatan dan kemacetan

d. Tempat parkir yang luas, nyaman, dan aman.

e. Ekspansi, yaitu tersedia tempat yang cukup luas untuk perluasan usaha dikemudian hari.

f. Lingkungan, yaitu daerah sekitar yang mendukung jasa.

g. Kompetisi, yaitu lokasi pesaing. 
h. Peraturan pemerintah, misalnya ketentuan yang melarang yang tidak baik bagi kesehatan.

\section{Promosi}

Zikmum (2011:27) mendefinisikan promosi merupakan fungsi komunikasi dari perusahaan yang bertanggung jawab menginformasikan dan membujuk/mengajak pembeli. Promosi merupakan salah satu faktor penentu keberhasilan suatu program pemasaran. Promosi merupakan cara khusus dari iklan pribadi, promosi penjualan dan hubungan masyarakat yang dipergunakan perusahaan untuk tujuan iklan dan pemasarannya. Hakikatnya promosi adalah suatu bentuk komunikasi pemasaran yang dimaksud dengan komunikasi pemasaran adalah aktivitas pemasaran yang berusaha menyebarkan informasi, mempengaruhi/membujuk dan mengingatkan pasar sasaran atas perusahaan dan produknya agar bersedia menerima, membeli dan loyal pada produk yang ditawarkan perusahaan yang bersangkutan Tjiptono (2008:219).

Promosi menurut Kotler dan Amstrong (2014:77) "Promotion refers to activities that communicate the merits of the product and persuade target customers to buy it". Sedangkan menurut Tjiptono (2015:387) "promosi merupakan elemen bauran pemasaran yang berfokus pada upaya menginformasikan, membujuk, dan mengingatkan kembali kepada konsumen akan merek dan produk perusahaan".

Indikator promosi menurut Kotler \& Keller (2009:24) yaitu:

1) Tenaga penjualan

2) Pemasaran Langsung

3) Promosi penjualan

4) Periklanan

\section{Keputusan Pembelian}

Keputusan pembelian merupakan salah satu komponen utama dari perilaku konsumen. Suatu keputusan melibatkan pilihan diantara dua atau lebih alternative tindakan atau perilaku. Pengertian mengenai perilaku konsumen oleh perusahaan selaku produsen segitu penting dan perlu diperhatikan lebih lanjut. Proses keputusan pembelian bukan sekedar didasarkan pada berbagai faktor yang akan mempengaruhi pembeli, melainkan didasarakan pada peranan dalam pembelian dan keputusan membeli.

Menurut Tjiptono (2008:21) bahwa keputusan pembelian adalah sebuah proses dimana konsumen mengenal masalahnya, mencari informasi mengenai produk atau merek tertentu dan mengevaluasi seberapa baik masing-masing alternatif tersebut dapat memecahkan masalahnya, yang kemudian mengarah kepada keputusan pembelian. Menurut Sangadji dan Sopiah (2018) bahwa keputusan pembelian adalah proses pengintegrasian yang mengombinasikan pengetahuan untuk mengevaluasi dua perilaku alternatif atau lebih, dan memilih salah satu di antaranya. Oleh karena itu untuk mempengaruhi keputusan pembelian bagi pelaku bisnis di bidang jasa klinik kecantikan ini, maka semakin membuat para pelakunya ditantang untuk dapat menciptakan diferensiasi unik dan positioning yang jelas sehingga konsumen dapat membedakan dengan para pesaingnya. Kondisi pasar yang kompetitif dan dinamis akan mengakibatkan setiap perusahaan harus selalu mengamati persaingan dalam lingkungan bisnisnya.

Dari definisi diatas perlu menarik kesimpulan bahwa keputusan pembelian adalah sebagai suatu proses dimana konsumen melakukan penilaian terhadap berbagai alternative pilihan dan memilih salah satu atau lebih alternatif yang diperlukan berdasarkan pertimbanganpertimbangan tertentu.

Tahap-tahap Proses Keputusan Pembelian Konsumen

Menurut Kotler, dkk. (2012: 179) ada beberapa tahapan dalam proses keputusan pembelian konsumen, yaitu : 
1) Pengenalan kebutuhan.

Merupakan tahap pertama dalam pross keputusan pembelian dimana konsumen mengenali permasalahan atau kebutuhan. Kebutuhan dapat dipicu oleh rangsangan internal ketika salah satu kebutuhan normal seseorang (rasa lapar, haus, sex) timbul pada tingkat yang lebih tinggi sehingga menjadi dorongan. Kebutuhan juga dipicu oleh rangsangan eksternal.

2) Pencarian informasi.

Merupakan tahap proses pengambilam keputusan pembeli dimana konsumen tergerak untuk mencari informasi tambahan, konsumen mungkin sekedar meningkatkan perhatian atau mungkin pula mencari informasi secara aktif.

Konsumen yang tertarik mungkin akan mencari lebih banyak informasi atau mungkin tidak. Jika dorongan itu kuat dan produk yang memuaskan ada di dekat konsumen itu, konsumen mungkin akan membelinya. Jika tidak, konsumen bisa menyimpan kebutuhan itu dalam ingatannya atau melakukan pencarian informasi.

3) Menentukan pembelian.

Menentukan pembelian merupakan tahap proses keputusan dimana konsumen secara aktual melakukan pembelian produk. Pada umumnya, keputusan pembelian konsumen adalah membeli merek yang paling mereka sukai, tetapi ada dua faktor yang dapat mempengaruhi hal tersebut yaitu sikap orang lain dan faktor situasional yang diharapkan. Ada dua hal yang dapat mempengaruhi keputusan pembelian yaitu sikap orang lain dan faktor situasi yang tak terduga yang dapat mengubah kecenderungan pembelian.

Adapun indikator yang digunakan untuk keputusan pembelian ini merujuk pada tahapan keputusan pembelian yang dilakukan konsumen menurut (Sudaryono, 2016:109) yaitu:
a. Pencarian informasi
b. Evaluasi alternarif
c. Keputusan Pembelian
d. Perilaku pasca pembelian

\section{Hipotesis}

Berdasarkan kerangka pikir diatas maka dirumuskan hipotesis sebagai berikut:

1. Terdapat pengaruh signifikan Produk terhadap Keputusan Pembelian Bibit Tanaman pada Kawasan Lubuk Minturun Kota Padang.

2. Terdapat pengaruh signifikan Harga terhadap Keputusan Pembelian Bibit Tanaman pada Kawasan Lubuk Minturun Kota Padang.

3. Terdapat pengaruh signifikan Lokasi terhadap Keputusan Pembelian Bibit Tanaman pada Kawasan Lubuk Minturun Kota Padang.

4. Terdapat pengaruh signifikan Promosi terhadap Keputusan Pembelian Bibit Tanaman pada Kawasan Lubuk Minturun Kota Padang.

5. Terdapat pengaruh signifikan Produk, Harga, Lokasi dan Promosi secara Bersama-sama terhadap kinerja Pegawai pegawai pada Dinas Kesehatan Kota (DKK) Padang.

\section{METODOLOGI PENELITIAN}

Penelitian ini dilakukan untuk mengetahui pengaruh Marketing Mix (Produk, Harga, Lokasi, Promosi) terhadap Keputusan Pembelian Bibit Tanaman pada Kawasan Lubuk Minturun Kota Padang. Penelitian ini merupakan penelitian eksplanatori yaitu penelitian yang menguji hipotesis yang ada. Metode yang digunakan dalam penelitian ini adalah metode kuantitatif dengan menggunakan metode survei. Penelitian kuantitatif adalah penelitian yang menekankan pada penggunaan pertanyaan dengan standar formal dan sebelumnya telah ditetapkan pilihan jawaban dalam kuesioner yang dibagikan kepada responden. Teknik pengumpulan data dengan survei ini menggunakan self administered survey yang mana masing- 
masing kuesioner diisi langsung oleh responden. Dalam penelitian ini digunakan 53 sampel yang disebarkan ke pembeli bibit tanaman pada kawasan lubuk minturun di Kota Padang.

Responden dari penelitian ini menggunakan beberapa kriteria sehingga menggunakan teknik accidental sampling. Hal ini dikarenakan dalam penelitian ini hanya orang-orang dengan kriteria yang telah ditentukan oleh peneliti yang dapat menyediakan informasi secara tepat. Kriteria responden yang digunakan dalam penelitian ini adalah wisatawan yang berkunjung ke objek wisata yang ada Pulau Mandeh Pesisir Selatan, Sumatera Barat.

Teknik pengumpulan data dilakukan dengan metode survei, yaitu metode pengumpulan data primer dengan memberikan atau menyebarkan daftar pertanyaan/pernyataan kepada responden dengan harapan memberikan respon atas daftar pertanyaan tersebut. Daftar pertanyaan/pernyataan dapat bersifat terbuka jika jawaban tidak ditentukan sebelumnya bersifat tertutup jika alternatif-alternatif jawaban telah disediakan instrumen yang berupa lembar daftar pertanyaan tadi dapat berupa kuesioner. Setiap pertanyaan mempunyai 5 jawaban, mulai dari sangat setuju, setuju, netral, tidak setuju dan sangat tidak setuju.

Sesuai dengan model penelitian diatas dan hipotesis yang telah dirumuskan, maka penelitian ini menggunakan analisis regresi melalui software SPSS untuk menganalisis data.

\section{HASIL DAN PEMBAHASAN}

Tabel 1. Hasil Uji Regresi Berganda Coefficients $^{\mathrm{a}}$

\begin{tabular}{|c|c|c|c|c|c|c|c|}
\hline \multirow[b]{2}{*}{ Model } & & \multicolumn{3}{|c|}{ Unstandardized Coefficients } & $\begin{array}{l}\text { Standardized } \\
\text { Coefficients } \\
\end{array}$ & \multirow[b]{2}{*}{$\mathrm{t}$} & \multirow[b]{2}{*}{ Sig. } \\
\hline & & B & & $\begin{array}{l}\text { Std. } \\
\text { Error }\end{array}$ & Beta & & \\
\hline \multirow[t]{5}{*}{1} & (Constant) & & 2,645 & 5,848 & &, 452 &, 653 \\
\hline & Total Produk & &, 415 & ,164 & ,352 & 2,539 &, 014 \\
\hline & Total Harga & & , 057 & ,264 &, 035 &, 216 &, 830 \\
\hline & Total Lokasi & & ,029 & ,114 & ,037 & ,251 & ,803 \\
\hline & $\begin{array}{l}\text { Total } \\
\text { Promosi }\end{array}$ & & ,465 &, 112 &, 532 & 4,160 & ,000 \\
\hline
\end{tabular}

a. Dependent Variable: Total Keputusan Pembelian

Berdasarkan tabel diatas maka dapat dilihat persamaan regresinya yaitu :

$$
Y=2,645+0,415 X_{1}+0,057 X_{2}+0,029 X_{3}+0,465 X_{4}+e
$$

Dari persamaan regresi berganda di atas dapat disimpulkan bahwa Koefisien regresi variabel Produk, Harga, Lokasi, Promosi berpengaruh positif dengan nilai sebagai berikut $\mathbf{Y}=$ $2,645+0,415 X_{1}+0,057 X_{2}+0,029 X_{3}+0,465 X_{4}+e$.

\section{Hipotesis}

Tabel 2 Hasil Uji-t

Coefficients $^{\mathbf{a}}$

\begin{tabular}{|c|c|c|c|c|c|c|}
\hline \multirow[b]{2}{*}{ Model } & & \multicolumn{2}{|c|}{$\begin{array}{l}\text { Unstandardized } \\
\text { Coefficients }\end{array}$} & \multirow{2}{*}{$\begin{array}{l}\text { Standardized } \\
\text { Coefficients } \\
\text { Beta }\end{array}$} & \multirow[b]{2}{*}{$\mathrm{t}$} & \multirow[b]{2}{*}{ Sig. } \\
\hline & & $\mathrm{B}$ & Std. Error & & & \\
\hline \multirow[t]{5}{*}{1} & (Constant) & 2,645 & 5,848 & &, 452 &, 653 \\
\hline & Total Produk &, 415 &, 164 & ,352 & 2,539 & ,014 \\
\hline & Total Harga & ,057 & ,264 & ,035 & ,216 & ,830 \\
\hline & Total Lokasi & ,029 &, 114 & ,037 &, 251 & ,803 \\
\hline & Total Promosi & ,465 & ,112 & ,532 & 4,160 & ,000 \\
\hline
\end{tabular}

a. Dependent Variable: Total Keputusan Pembelian 
Pada tabel 2 diatas dapat disimpulkan bahwa Produk berpengaruh signifikan terhadap Keputusan Pembelian Bibit Tanaman pada Kawasan Lubuk Minturun Kota Padang dengan tingkat signifikan sebesar 0,014 dikarenakan nilai signifikannya lebih kecil dibandingkan alpha 0,05 atau 5\%. Harga tidak berpengaruh signifikan terhadap Keputusan Pembelian Bibit Tanaman pada Kawasan Lubuk Minturun Kota Padang dengan tingkat signifikan sebesar 0,830 dikarenakan nilai signifikannya lebih besar dibandingkan alpha 0,05 atau 5\%.. Lokasi tidak berpengaruh signifikan terhadap Keputusan Pembelian Bibit Tanaman pada Kawasan Lubuk Minturun Kota Padang dengan tingkat signifikan sebesar 0,803 dikarenakan nilai signifikannya lebih besar dibandingkan alpha 0,05 atau 5\%.. Promosi berpengaruh signifikan terhadap Keputusan Pembelian Bibit Tanaman pada Kawasan Lubuk Minturun Kota Padang dengan tingkat signifikan sebesar 0,000 dikarenakan nilai signifikannya lebih kecil dibandingkan alpha 0,05 atau $5 \%$.

\section{Pengujian Hipotesis Secara Simultan (Uji F)}

\begin{tabular}{|c|c|c|c|c|c|c|}
\hline & & $\begin{array}{c}\text { Tabel } 3 \text { Hasil Uji F } \\
\text { ANOVA }^{\mathrm{a}}\end{array}$ & & & & \\
\hline Model & & Sum of Squares & df & $\begin{array}{l}\text { Mean } \\
\text { Square }\end{array}$ & $\mathrm{F}$ & Sig. \\
\hline \multirow[t]{3}{*}{1} & Regression & 1546,728 & 4 & 386,682 & 17,689 &, $000^{\mathrm{b}}$ \\
\hline & Residual & 1049,272 & 48 & 21,860 & & \\
\hline & Total & 2596,000 & 52 & & & \\
\hline
\end{tabular}

a. Dependent Variable: TotalY

b. Predictors: (Constant), TotalX4, TotalX1, TotalX3, TotalX2

Berdasarkan Tabel diatas dapat kita lihat, bahwa seluruh tingkat signifikan antara masingmasing variabel $<0,050$, maka dapat disimpulakan bahwa secara simultan atau seluruh varibel berpengaruh positif dan siginifikan terhadap $\mathrm{Y}$.

\section{KESIMPULAN}

1. Pengaruh Produk terhadap Keputusan Pembelian Bibit Tanaman

Berdasarkan hasil analisis data penelitian ketahui nilai koefisien regresi Produk positif sebesar 0,415 dan tingkat siginifikan $(0,014<0,05)$, artinya secara parsial terdapat pengaruh yang signifikan antara Produk terhadap Keputusan Pembelian Bibit Tanaman pada Kawasan Lubuk Minturun Kota Padang.

2. Pengaruh Harga terhadap Keputusan Pembelian Bibit Tanaman

Berdasarkan hasil analisis data penelitian ketahui nilai koefisien regresi Harga positif sebesar 0,057 dan tingkat siginifikan $(0,830<0,05)$, artinya secara parsial terdapat pengaruh yang tidak signifikan antara Harga terhadap Keputusan Pembelian Bibit Tanaman pada Kawasan Lubuk Minturun Kota Padang.

3. Pengaruh lokasi terhadap Keputusan Pembelian Bibit Tanaman

Berdasarkan hasil analisis data penelitian ketahui nilai koefisien regresi Lokasi positif sebesar 0,029 dan tingkat siginifikan $(0,803<0,05)$, artinya secara parsial terdapat pengaruh yang tidak signifikan antara Lokasi terhadap Keputusan Pembelian Bibit Tanaman pada Kawasan Lubuk Minturun Kota Padang.

4. Pengaruh Promosi terhadap Keputusan Pembelian Bibit Tanaman

Berdasarkan hasil analisis data penelitian ketahui nilai koefisien regresi Promosi positif sebesar 0,465 dan tingkat siginifikan $(0,000<0,05)$, artinya secara parsial terdapat pengaruh yang signifikan antara Promosi terhadap Keputusan Pembelian Bibit Tanaman pada Kawasan Lubuk Minturun Kota Padang.

5. Pengaruh Produk, Harga, Lokasi dan Promosi terhadap Keputusan Pembelian Bibit Tanaman

Berdasarkan hasil analisis data penelitian ketahui bahwa seluruh tingkat signifikan antara masing-masing variabel $<0,050$, maka dapat disimpulakan bahwa secara simultan atau 
seluruh varibel berpengaruh positif dan siginifikan terhadap Y, artinya secara simultan atau seluruh terdapat pengaruh yang signifikan Promosi, Harga, Lokasi dan Promosi terhadap Keputusan Pembelian Bibit Tanaman pada Kawasan Lubuk Minturun Kota Padang.

\section{DAFTAR PUSTAKA}

[1] Tjiptono, Fandy. (2014). Pemasaran Jasa, edisi pertama, cetakan kesepuluh, Penerbit : Andi Yogyakarta

[2] Payne, Adrian, 2012, The essence of service marketing. Penerbit ANDI \& Pearson Education (Asia) pte. Ltd., Yogyakarta

[3] Assauri, Sofjan, 2011. Manajemen Pemasaran. Cetakan ke-11. Penerbit PT RajaGrafindo Persada. Jakarta.

[4] Tjiptono, Fandy, 2008. Strategi Pemasaran. Edisi Ketiga. Penerbit ANDI. Yogyakarta.

[5] Zikmun, Babin, 2011. Riset Pemasaran. Edisi Sepuluh. Penerbit Salemba Empat. Jakarta

[6] Sangadji, Mamang Etta dan Sopiah. (2018). Perilaku Konsumen, Pendekatan Praktis disertai Himpunan Jurnal Penelitian. Penerbit : Andi, Yogyakarta.

[7] Kotler, dan keller. (2012). Manajemen Pemasaran, Edisi 12. Jakarta: Erlangga

[8] Sudaryono. (2016). MAanajemen Pemasaran. Yogyakarta: Cv Andi Offset.

[9] Kotler, P., \& Keller, kevin lane. (2009). Manajemen Pemasaran (13th ed.). Jakarta: Pt. Gelora Aksara Pratama.

[10] Kotler, Philip dan Amstrong, Gary, (2014), Principles of Marketin, 12th Edition, Jilid 1 Terjemahan Bob Sabran Jakarta : Erlangga.

[11] Fandy Tjiptono, Ph.D. 2015. Strategi Pemasaran, Edisi 4, Penerbit Andi, Yogyakarta

[12] Tjiptono, Fandy. 2014. Pemasaran Jasa (Prinsip, Penerapan, dan Penelitian). Yogyakarta : Andi

[13] Pengaruh Kualitas Produk, Harga, Lokasi, Dan Kualitas Layanan Terhadap Keputusan Pembelian Di Djawi Lanbistro Coffee And Resto Surabaya

[14] Barcelona, Oktavianus, M. Tumbel, Tinneke, Kalangi, John A. F. (2019). Pengaruh Marketing Mix Terhadap Keputusan Pembelian Pada Cv. Justiti Motor Lembata. Jurnal Administrasi Bisnis Vol. 8. No. 2, 2019 (P-Issn 2338-9605; E-2655-206x)

[15] Suhartini, Said, Syahnur. (2019). Pengaruh Marketing Mix Terhadap Keputusan Pembelian Pada Klinik Kecantikan Di Kota Makassar. CESJ : Center of Economic Student Journal. Vol. 2. No. 2 April (2019)

[16] Winarni, Eko, Jamianto (2019). Pengaruh Marketing Mix Terhadap Keputusan Pembelian Produk Jasa Pada Villa Abc Malang. Yos Soedarso Economics Journal Volume 1 Nomor 1, April 2019 ISSN 2684-9720 